\title{
PSYCHIATRIC MORBIDITIES, PERSONALITY TEMPERAMENT AND COPING STYLE IN A SAMPLE OF EGYPTIAN PATIENTS WITH ISCHEMIC HEART DISEASE

\author{
Ahmed Saad ${ }^{1}$, Mona Elsheikh ${ }^{1}$, Ahmed Onsi ${ }^{2}$,Marwa Sultan ${ }^{1}$,Walaa Sabry ${ }^{1}$,and \\ Mariam Shehata ${ }^{1}$
}

\begin{abstract}
${ }^{1}$ Department of Neurology and Psychiatry, and ${ }^{2}$ Department of Cardiology. Faculty of Medicine, Ain Shams University, Cairo, Egypt

\section{Corresponding :}

Mariam Mohamed M. Shehata Mobile: 01003509152

E mail:
\end{abstract}

Mariam.shehata251@gmail.com Received: 26/5/2019

Accepted: 19/6/2019

\begin{abstract}
:
Back Ground: Ischemic heart disease (IHD) is the leading cause of death worldwide. It is responsible for up to one third of deaths. Moreover it will be the most common reason of mortality in the world by the year 2030. In Egypt, IHD is the leading cause of death according to world health organization (WHO) .Over the past 20 years there has been growing evidence of a link between psychiatric disorders and cardiovascular disease. This link has been shown in multiple studies linking psychiatric disorders with an increase in mortality from (IHD).
\end{abstract}

Aim of work: To identify psychiatric comorbidities the temperament of the personality among patients with different groups of ischemic heart diseases.To study the coping style among patients with Coronary artery diseases.

Patients and Methods: Cases were selected from patients attending the cardiology clinics and coronary catheterization unit in cardiology department, Ain shams University Hospitals. They were divided into three groups and the controlA written informed consent was obtained from all patients involved in the study and the subjects are given a detailed explanation of the nature and aim of the study. General heath questionnaire was done for all patients for screening followed by SCID to detect the psychiatric comorbidities and follow up after one month, then TCIR to detect the personality temperament and Coping process scale to detect the coping styles in the study sample.

Results: Following the screening, SCID was done for diagnosis of psychiatric disorders..Our results shows statically significance difference between group A, group $B$,group $C$ and the control as regard psychiatric disorders inculding depression and anxiety with ( $\boldsymbol{p}$ value $<0.001$ ).

Conclusion: our results suggested screening for psychiatric disorders in Ischemic heart disease patients as they were more prevalent in CHD than in normal population.

Keywords: Ischemic heart diseases (IHD), Depression , Coping , personality, comorbidities .

Role of researchers

All authors contributed to the production for this manuscript. M.S was responsible for the field work.

\section{INTRODUCTION}

Cardiovascular diseases (CVDs) are the leading cause of death in almost every region of the world ${ }^{(\mathbf{1})}$ According to the
World Health Organization (WHO), CVDs account for 17.7 million or $31 \%$ of all deaths worldwide. An estimated 7.4 million of these deaths are due to coronary heart disease (CHD) $)^{(2)}$ 
CHD, also known as ischemic heart disease or coronary artery disease is a common term for the build up of a waxy substance, called plaque, in the heart's arteries, leading to the failure of coronary circulation to supply adequate blood circulation to cardiac muscle and surrounding tissue - a phenomenon that can result in a myocardial infarction (MI) ${ }^{(3)}$

Acute rupture of plaque in the coronary artery resulting in flow-limiting lesion is one of the important mechanisms of acute coronary syndrome (ACS) which include ST-segment elevation myocardial infarction (STEMI), nonSTEMI (NSTEMI), and unstable angina $(\mathrm{USA})^{(4)}$

An intriguing relationship between mental illness and CHD appears to exist. A higher prevalence of mental diseases in CHD patients has been demonstrated. Conversely, people suffering from a mental disease seem to have an increased risk of CHD. A common pathophysiological mechanisms may link both diseases ${ }^{(5)}$

Type D personality is specified by a combination of two fixed personality structure: negative affectivity and social inhibition $^{(6)}$ Negative affectivity is the tendency to experience negative emotions constantly such as restlessness, boredom, fear and irritability in all times and situations. Social inhibition is the intendancy to inhibit expressing the emotions, high levels of insecurity experience in social situations and extreme control of selfrevelation for fear of others' displeasures ${ }^{(7)}$.

Type D personality is relatively common. The estimations show a range of $21-28 \%$ of cardiovascular patients and $53 \%$ of the people with high blood pressure among the public population. ${ }^{(8)}$

Coping strategies are generally divided into adaptive and maladaptive coping strategies. Reactions like rumination, aggression, and passive avoidance have been considered as maladaptive coping strategies, and adaptive coping strategies include learning new skills, seeking help, and venting anger. ${ }^{(9)}$

\section{AIM OF WORK:}

To identify psychiatric comorbidities, the temperament of the personality among patients with different groups of ischemic heart diseases.

To study the coping style among patients with Coronary artery diseases.

\section{PATIENTS AND METHODS:}

1) Type of the study: This is a cross sectional descriptive and comparative study.

2) Site of the study: Cases were selected from patients attending the cardiology clinics and coronary catheterization unit in cardiology department, Ain shams University Hospitals.

The cardiology department Ain Shams University hospitals are located in western Cairo, serving both urban and rural areas, including greater Cairo and other governorates as well. The Cardiology clinic is available 3 times per week; each clinic serves about 50 patients.

The catheterization unit is working 6 days per week and serves around 30 to 40 patients per day.

3) Subjects: The cases diagnosed with IHD were divided into 3 groups; According to the number of vessels affected in the diagnostic angiography to :

1. Patients for conservative medical treatment.

2. Patients for Percutaneous Coronary Intervention (PCI).

3. Patients for Coronary artery bypass graft (CABG). 
- $\quad$ Each group was consisted of 30 patients. All patients fulfilling the inclusion criteria offered to participate in the study until completion of the sample size.

The sample size was calculated by the community department Ain shams university.

\section{Permits and approval:}

The following approvals were obtained in order to conduct the study:

- Approval from department of Cardiology Ain Shams University.

- Approval of the ethical committee of Faculty of medicine Ain Shams University.

\section{Inclusion and exclusion criteria:}

Patients included should fulfil the following criteria,

1) Age: ranges between $18-60$ years to exclude the effect of age(a before 18 years personality is still not well developed and after age of 60 years the effect of aging will affect on personality profile).

2) Gender: males and females.

3) Consenting patients using a written informed consent.

Presence of current Axis I psychiatric disorder is excluded.

\section{4) Procedures:}

A- A written informed consent will be obtained from all patients involved in the study and the subjects are given a detailed explanation of the nature and aim of the study.

B- Study proper:

1. Cardiological Assessment will be done including cardiological examination and investigations (ECG, echo, diagnostic angiography).
2. Sociodemographic data will be collected by self-designed questionnaire according to the psychiatric sheet of the institute of psychiatry Ain Shams University.

3. The cases and controlswill be assessed using the following measures:

a) General Health questionnaire (GHQ) for screening of psychiatric disorders.

b) Structured Clinical Interview for DSM-IV Axis I Disorders (SCID I) for axis I diagnosis.

c) The Temperament and Character Inventory (TCI).

d) Copingprocesses scale.

5) Date analysis

Statistics was done using SPSS Statistics version 22, it is a software package used for statistical analysis. Long produced by SPSS Inc., it was acquired by IBM in 2009. A $p$ value of $<0.05$ was considered significant and a $\mathrm{p}$ value of $<0.01$ was considered highly significant.

\section{RESULTS:}

\section{Sociodemographic data of each group of} the study sample.

\section{In our sample:}

As regard Group (A): Ourresults showed that $80 \%$ of the patients lies between 50-60 years as regard the age $(n=24)$, As regard the gender we found that $60 \%$ of the patients are males $(n=18)$.Italsoshowed that $87 \%$ lives in urban areas $(n=26)$. Moreover it was found that $37 \%$ of them areTechnical graduate $(\mathrm{n}=11)$ and $53 \%$ were employed $(\mathrm{n}=16)$. when asking about the marital status it was found that $83 \%$ of the group (A) are married $(\mathrm{n}=25)$.

As regard Group (B): It was found that $67 \%$ of this group between $50-60$ years as regard the age $(n=20)$. As regard the gender $80 \%$ of the patients were males 
$(n=24) . i t$ is showed in the results that $87 \%$ lives in urban areas $(n=26)$. Also it was found that $30 \%$ of them areTechnical graduate $(\mathrm{n}=9)$ and $77 \%$ are employed $(n=23)$.when asking about the marital status $87 \%$ of the group $(\mathrm{B})$ are married $(\mathrm{n}=26)$.

As regard Group (C):it was found that $87 \%$ of the patients between $50-60$ years as regard the age $(n=26)$. As regard the gender $93 \%$ of the patients are males $(n=28)$.As regard the the residence $93 \%$ lives in urban areas $(n=28)$. Also it as found that $63 \%$ of the group areilliterate $(\mathrm{n}=19)$ and $60 \%$ are employed $(\mathrm{n}=16)$.when asking about the marital status $90 \%$ of the group (C) are married $(n=27)$.

As regard control group: the results showed that $63 \%$ of this group between 50 60 years as regard the age $(n=19)$. As regard the gender $63 \%$ of the patients are males $(n=19)$.as regard the residence $77 \%$ of this group lives in urban areas $(n=23)$. Also it was found that $33 \%$ have Bachelor degree $(n=10)$ and $90 \%$ are employed $(n=27)$.As regard the marital status $83 \%$ of the control are married $(n=25)$.

Table (1): shows the sociodemograhic data of the cases and the controls.

\begin{tabular}{|c|c|c|c|c|c|c|c|c|c|c|c|}
\hline & & \multicolumn{10}{|c|}{ Groups } \\
\hline & & \multicolumn{2}{|c|}{$\begin{array}{l}\text { Medical ttt } \\
\text { Group (A) }\end{array}$} & \multicolumn{2}{|c|}{$\begin{array}{c}\text { PCI } \\
\text { Group (B) } \\
\end{array}$} & \multicolumn{2}{|c|}{$\begin{array}{c}\text { CABG } \\
\text { Group (C) }\end{array}$} & \multicolumn{2}{|c|}{ Control } & \multicolumn{2}{|c|}{ Total } \\
\hline & & $\mathrm{N}$ & $\%$ & $\mathrm{~N}$ & $\%$ & $\mathrm{~N}$ & $\%$ & $\mathrm{~N}$ & $\%$ & $\mathrm{~N}$ & $\%$ \\
\hline \multirow[t]{3}{*}{ Age } & 30-39 Years & 0 & 0.00 & 3 & 10.00 & 1 & 3.33 & 5 & 16.67 & 9 & 7.50 \\
\hline & 40-49 Years & 6 & 20.00 & 7 & 23.33 & 3 & 10.00 & 6 & 20.00 & 22 & $18 . .33$ \\
\hline & 50-60 Years & 24 & 80.00 & 20 & 66.67 & 26 & 86.67 & 19 & 63.33 & 89 & 74.17 \\
\hline \multirow[t]{2}{*}{ Gender } & Male & 18 & 60.00 & 24 & 80.00 & 28 & 93.33 & 19 & 63.33 & 89 & 74.17 \\
\hline & Female & 12 & 40.00 & 6 & 20.00 & 2 & 6.67 & 11 & 36.67 & 31 & 25.83 \\
\hline \multirow[t]{2}{*}{ Residence } & Urban & 26 & 86.67 & 26 & 86.67 & 28 & 93.33 & 23 & 76.67 & 103 & 85.83 \\
\hline & Rural & 4 & 13.33 & 4 & 13.33 & 2 & 6.67 & 7 & 23.33 & 17 & 14.17 \\
\hline \multirow[t]{6}{*}{ Education } & Illiterate & 14 & 46.67 & 15 & 50.00 & 19 & 63.33 & 2 & 6.67 & 50 & 41.67 \\
\hline & Primary school & 0 & 0.00 & 0 & 0.00 & 1 & 3.33 & 0 & 0.00 & 1 & 0.83 \\
\hline & Secondary School & 1 & 3.33 & 2 & 6.67 & 5 & 16.67 & 3 & 10.00 & 11 & 9.17 \\
\hline & Technical raduate & 11 & 36.67 & 9 & 30.00 & 4 & 13.33 & 7 & 23.33 & 31 & 25.83 \\
\hline & Bachelor degree & 4 & 13.33 & 4 & 13.33 & 1 & 3.33 & 10 & 33.33 & 19 & 15.83 \\
\hline & Post graduate & 0 & 0.00 & 0 & 0.00 & 0 & 0.00 & 8 & 26.67 & 8 & 6.67 \\
\hline \multirow[t]{4}{*}{ Occupation } & Unemployed & 3 & 10.00 & 1 & 3.33 & 10 & 33.33 & 0 & 0.00 & 14 & 11.67 \\
\hline & House wife & 1 & 3.33 & 1 & 3.33 & 0 & 0.00 & 0 & 0.00 & 2 & 1.67 \\
\hline & Sick leave & 10 & 33.33 & 5 & 16.67 & 2 & 6.67 & 3 & 10.00 & 20 & 16.67 \\
\hline & Employed & 16 & 53.33 & 23 & 76.67 & 18 & 60.00 & 27 & 90.00 & 84 & 70.00 \\
\hline \multirow{4}{*}{$\begin{array}{l}\text { Marital } \\
\text { Status }\end{array}$} & Single & 1 & 3.33 & 2 & 6.67 & 1 & 3.33 & 4 & 13.33 & 8 & 6.67 \\
\hline & Married & 25 & 83.33 & 26 & 86.67 & 27 & 90.00 & 25 & 83.33 & 103 & 85.83 \\
\hline & Divorced & 0 & 0.00 & 1 & 3.33 & 0 & 0.00 & 1 & 3.33 & 2 & 1.67 \\
\hline & Widow & 4 & 13.33 & 1 & 3.33 & 2 & 6.67 & 0 & 0.00 & 7 & 5.83 \\
\hline
\end{tabular}

\section{Detection of psychiatric comorbidities}

And when it comes to the psychiatric assessment, General health questionnaire was done to all the cases and the control then SCID was done for the diagnosis of psychiatric disorders to those with GHQ positive and follow up SCID was done also 1 month later.

It was found that $33 \%(n=10)$ of group A were GHQ positive and in Group (B) $57 \%(\mathrm{n}=17)$ were positive also in Group (C) $60 \%(n=18)$ were positive. 
Psychiatric morbidities, personality temperament and coping style in a sample of egyptian patients..

Table (2): shows the psychiatric comorbidities among the study groups and the control.

\begin{tabular}{|c|c|c|c|c|c|c|c|c|c|c|c|c|c|}
\hline & \multicolumn{10}{|c|}{ Groups } & \multirow{2}{*}{\multicolumn{2}{|c|}{ Chi-Square }} \\
\hline & & \multicolumn{2}{|c|}{$\begin{array}{l}\text { Medical ttt } \\
\text { Group A }\end{array}$} & \multicolumn{2}{|c|}{$\begin{array}{c}\text { PCI } \\
\text { Group B }\end{array}$} & \multicolumn{2}{|c|}{$\begin{array}{l}\text { CABG } \\
\text { Group C }\end{array}$} & \multicolumn{2}{|c|}{ Control } & \multicolumn{2}{|c|}{ Total } & & \\
\hline & & $\mathrm{N}$ & $\%$ & $\mathrm{~N}$ & $\%$ & $\mathrm{~N}$ & $\%$ & $\mathrm{~N}$ & $\%$ & $\mathrm{~N}$ & $\%$ & $\mathrm{X}^{2}$ & P-value \\
\hline \multirow[t]{2}{*}{ GHQ } & positive & 10 & 33.33 & 17 & 56.67 & 18 & 60.00 & 0 & 0.00 & 45 & 37.50 & \multirow[t]{2}{*}{29.404} & \multirow{2}{*}{$\begin{array}{c}<0.001 \\
*\end{array}$} \\
\hline & negative & 20 & 66.67 & 13 & 43.33 & 12 & 40.00 & 30 & 100.00 & 75 & 62.50 & & \\
\hline \multirow[t]{8}{*}{ SCID 1} & Depression & 0 & 0.00 & 2 & 6.67 & 6 & 20.00 & 0 & 0.00 & 8 & 6.67 & \multirow[t]{8}{*}{47.203} & \multirow[t]{8}{*}{$0.001^{*}$} \\
\hline & Anxiety & 2 & 6.67 & 5 & 16.67 & 4 & 13.33 & 0 & 0.00 & 11 & 9.17 & & \\
\hline & PTSD & 1 & 3.33 & 0 & 0.00 & 0 & 0.00 & 0 & 0.00 & 1 & 0.83 & & \\
\hline & Somatization & 1 & 3.33 & 0 & 0.00 & 0 & 0.00 & 0 & 0.00 & 1 & 0.83 & & \\
\hline & Adjustment & 2 & 6.67 & 5 & 16.67 & 5 & 16.67 & 0 & 0.00 & 12 & 10.00 & & \\
\hline & Free & 24 & 80.00 & 16 & 53.33 & 11 & 36.67 & 30 & 100.00 & 81 & 67.50 & & \\
\hline & $\begin{array}{l}\text { Anxiety\& } \\
\text { Adjustment }\end{array}$ & 0 & 0.00 & 1 & 3.33 & 2 & 6.67 & 0 & 0.00 & 3 & 2.50 & & \\
\hline & $\begin{array}{l}\text { Depression \& } \\
\text { Anxiety }\end{array}$ & 0 & 0.00 & 1 & 3.33 & 2 & 6.67 & 0 & 0.00 & 3 & 2.50 & & \\
\hline \multirow{6}{*}{$\begin{array}{l}\text { SCID 1 } \\
\text { (1 Month) }\end{array}$} & Depression & 0 & 0.00 & 1 & 3.33 & 11 & 36.67 & 0 & 0.00 & 12 & 10.00 & \multirow[t]{6}{*}{49.613} & \multirow{6}{*}{$\begin{array}{c}<0.001 \\
*\end{array}$} \\
\hline & Anxiety & 2 & 6.67 & 6 & 20.00 & 4 & 13.33 & 0 & 0.00 & 12 & 10.00 & & \\
\hline & PTSD & 1 & 3.33 & 0 & 0.00 & 0 & 0.00 & 0 & 0.00 & 1 & 0.83 & & \\
\hline & Somatization & 1 & 3.33 & 0 & 0.00 & 0 & 0.00 & 0 & 0.00 & 1 & 0.83 & & \\
\hline & Adjustment & 0 & 0.00 & 1 & 3.33 & 0 & 0.00 & 0 & 0.00 & 1 & 0.83 & & \\
\hline & Free & 26 & 86.67 & 22 & 73.33 & 15 & 50.00 & 30 & 100.00 & 93 & 77.50 & & \\
\hline
\end{tabular}

So, Depression was found in two patients in group B and six patients in group C.

- Anxiety was found in two patients in Group A, five patients in group B and four patients in group $\mathrm{C}$.

Follow up SCID after one month showed that depression was found in one patient in group $\mathrm{B}$ and eleven patients in group C.

Moreover anxiety was found in two patients in group A, six patients in group B and four patients in group $\mathrm{C}$.

\section{DISCUSSION:}

The World Health Organization (WHO) reports that cardiovascular diseases contribute to 17.5 million deaths per year and depressive disorders are the fourth leading cause of the global disease burden. By 2020, it is estimated that depression would be the second most common cause of death worldwide surpassing the other conditions. A bidirectional relationship has been noted between cardiovascular diseases and psychiatric comorbidities.. ${ }^{(\mathbf{1 0})}$

When studying the Socio-demographic of the study samplethe current study sample included 70 male patients and 20 female patients also 19 male controls and 11 female controls with total $74 \%$ males and $26 \%$ females. Ages ranged from 30-60 years in both patients and controls with the majority of the sample fall between 50-60 years with no statistical significance as regard age $(\mathrm{P}-$ value: 0.140). This shows agreement with Borham et al. (2014)who found 67.4\% were male patients and $32.6 \%$ were female patients, with age ranging from 30 to 70 years in their study sample. ${ }^{(11)}$

However, in contrast to the current results Yazadi et al. (2008) study have reported an older average age of presentation in their sample, which could be attributed to different inclusion criteria as patients with age up to 80 years were included in their study whereas in our study age range was (18-60) years Among our sample we found as regard the Past History of psych disorders there is only one patient in Group A and 
another one in Group C. previously sought psychiatric consultation yet they received any medical treatment this is line with Bezjanetal.,(2016) who found no patients in this study sample had history of psychiatric disorders. ${ }^{(\mathbf{1 2})(\mathbf{1 3})}$

In our study, 45 patientsreached the cut off value of the GHQ which is 7. They arefurther assessed by (SCID) for diagnosis of different psychiatric disorders.

In group (A) we found that $80 \%(n=24)$ were free from any psychiatric disorders whereas $7 \%(\mathrm{n}=2)$ was found to have adjustment disorder and Anxiety respectively. Also one patient with PTSD and one with somatizationSimilar findings were reported by Bankier et al.2004 their results showed that Generalized anxiety disorder is most common psychiatric disorder found in stable patients with CAD on conservative medical treatment .However they found that recurrent depression is the second most common followed by PTSD and alcohol abuse one this is may be explained by the stigma of the psychiatric disorders so most of patients deny any of the symptoms and also by the fact that Bankier et al.2004 study was done for the outpatients stable patients only in contrary to our patients that include the patients in the inpatient setting followed the diagnostic angiography ${ }^{(\mathbf{1 4})}$.

$>$ Group (B) It was found that $17 \%(n=5)$ have anxiety disorder, $17 \%(n=5)$ have adjustment disorder then depression is found in $7 \%(\mathrm{n}=2)$ in this group. this is not line with Abrams et al.,2009 who found depression is the most common followed by Anxiety also this may be explained that they collected their sample from outpatients and inpatients settings (15)

> As regard group (C)we also found that $20 \% \quad(n=6)$ of this group was diagnosed by Depression according to the SCID, $17 \%(n=5)$ had adjustment disorder then Anxiety is found in $13 \%$ $(n=4)$ also $6 \%$ had mixed anxiety depression. Also Lichtman et al.,2008 employing 1176 undergoing CABG surgery reported in their study that depression followed by Anxiety are the most common psychiatric disorders found in patients For CABG.

In conclusion the current study found the most common psychiatric disorder found was Adjustment disorder (12\%) of the cardiac patients followed by Anxiety disorder $(11 \%)$ then depression in $(9 \%)$ of the sample, Mixed anxiety depression in (3\%) and lastly each of PTSD and somatization is $(3 \%)$ of the patients with different grades of IHD $^{(\mathbf{1 6})}$.

\section{Recommendations:}

Educational programs to raise awareness of the psychiatric comorbidities among the cardiological diseases especially the ischemic heart diseases patients.

Educational programs to raise awareness of the personality temperament and the coping styles among cardiologists.

\section{Limitation:}

The small sample size, so that the results could not be generalized.

Not a well-representative community sample, as the sample was collected from Ain Shams University hospital only.

\section{Declaration:} interest.

All authors declared no conflict of

\section{REFERENCES:}

1. Foley JR., Plein S., and Greenwood JP (2017). Assessment of stable coronary artery disease by cardiovascular magnetic resonance imaging: current and emerging techniques. World J Cardiol;9(2):92-108. 
2. World Health Organization (2017). Cardiovascular diseases (CVDs). Fact sheet, updated May 2017. Available at: http:// www.who.int/mediacentre/factsheets/fs317/ en/. Accessed December 18, 2017.

3. American Heart Association (2017)

Available at:

http://www.heart.org/HEARTORG/Conditi ons/HeartAttack/TreatrnentofaHeartAttack/ Silentlschemia-and-lschemic-HeartDisease_UCM_434092_Article.jsp\#.WZ_p PT-5JaUI. Accessed December 18, 2017.

4. Kumar A, Cannon CP(2009) Acute coronary syndromes: Diagnosis and management, part I. Mayo Clin Proc.;84:917-938.

5. Marc De Hert, Johan Detraux and Davy Vancampfort (2018). The intriguing relationship between the the coronary heart diseases and mental disorders Dialogues ClinNeurosci. Mar; 20(1): 31-40.

6. Pedersen SS, DenolletJ.(2006) Is Type D personality here to stay? Emerging evidence across cardiovascular disease patient groups. Current Cardiology Reviews. ; 2(3):205-13.

7. Denollet J, Vaes J, BrutsaertDL.(2000) Inadequate response to treatment in coronary heart disease: adverse effects of type D personality and younger age on 5year prognosis and quality of life. Circulation; 102 (6): 630-5

8. Kupper N, Pedersen SS, Saner H,etal (2013). Cross-cultural analysis of Type D (distressed) personality in 6222 patients with ischemic heart disease: A study from the International Heart QoL Project. International journal of cardiology.; 166 (2): 327-33.

9. Kristofferzon ML, lofmark R, carlsson M (2005) .coping, social support and quality of life over time after myocardial infraction. $\mathrm{J}$ Advnurs: 360-386
10. Shruthi R, Kumar S,Desai N etal.,(2018) psychiatric comorbidities in acute coronary syndrome: Six month follow up study Indian journal of psychiatry ;60(1);60-64.

11. Borham M, El-AtrounyM, Abo El-Hoda M, etal.(2014) Psychiatric morbidity and lifestyle of patients with coronary artery disease in Nile deltaEgyptian Journal of Psychiatry, 35(2):80-88.

12. Yazdi S.M ,HosseinianS,eslam $M$ etal (2008) quality of life and coping stragies in coronary heart disease pateints ,journal of applies sciences 8(11); 707-710

13. CigdemHazalBezgin, Tahir Bezgin, and SerminKesebir(2016)TemperamentandChar acterProfilesandPsychiatricComorbiditiesin PatientsWithCoronaryArteryorValvularHea rtDisease:RelationshipWithCardiacDisease Severity:Journalofclinicalpsychiatryresearc h.; 8(3): 202-209

14. Bankier, B, Januzzi, L., Littman, B.etal.,(2004)The High Prevalence of Multiple Psychiatric Disorders in Stable Outpatients With Coronary Heart Disease Psychosomatic Medicine: - 66 ( 5) : 645650.

15. Abrams T; Sarrazin M; Rosenthal G (2009)Psychiatric Comorbidity and Mortality after Acute Myocardial Infarction Circ Cardiovasc Qual Outcomes.; 2: 213220.

16. Lichtman, J. H. et al. (2008) Depression and coronary heart disease: recommendations for screening, referral, and treatment: a science advisory from the American Heart Association Prevention Committee of the Council on Cardiovascular Nursing, Council on Clinical Cardiology, Council on Epidemiology and Prevention, and Interdisciplinary Council on Quality of Care and Outcomes Research: endorsed by the American Psychiatric Association. Circulation 118, 1768-1775. 


\section{الاضطرابات النفسية وطبع الشخصية ونمط التكيف في عينة من المرضى المصريين المصابين بداء القلب الإقفاري}

أحمد سعد محمد ومنى محمود الشيخ و أحمــد محمـــ أنســى ومروة عبد الرحمن سلطان و ولاء محمد صبرى

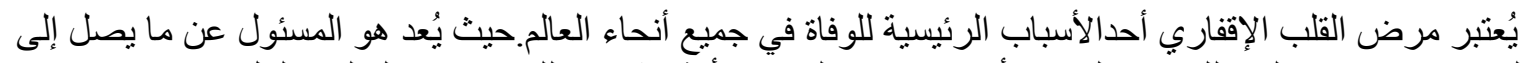

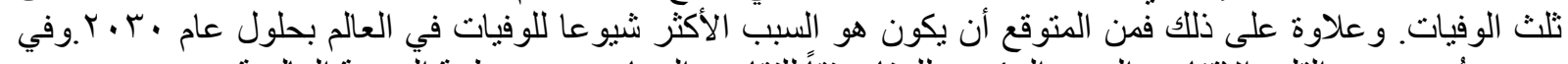

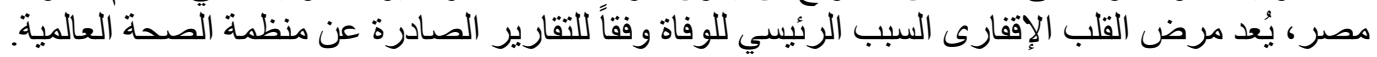

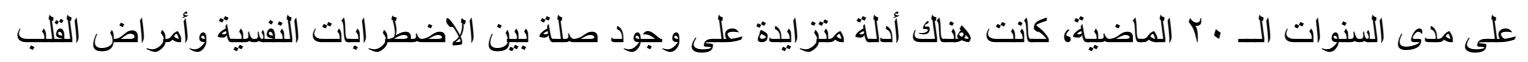

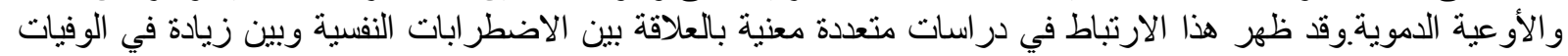
الناجمة عن مرض القلب الإقفارى.

الغرض من الدراسة تحديد مجمو عة مختلفة من العوامل الديموجر افية المصاحبة لمرض القلب الإقفارى.

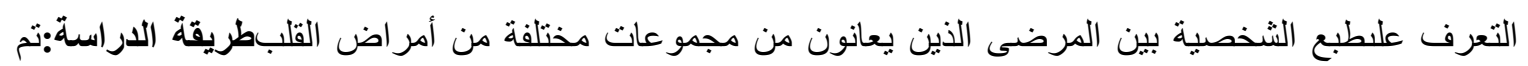

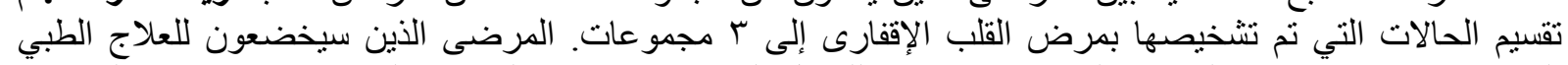

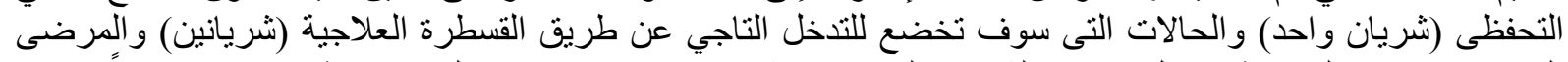

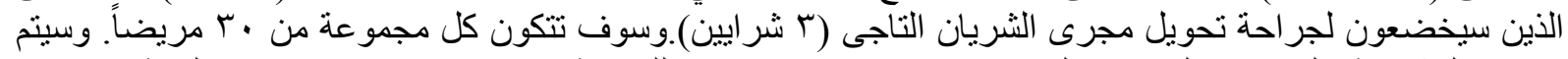

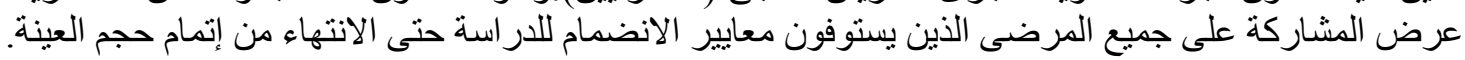

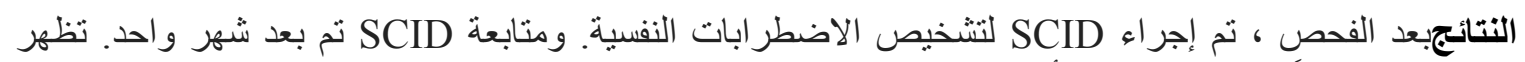

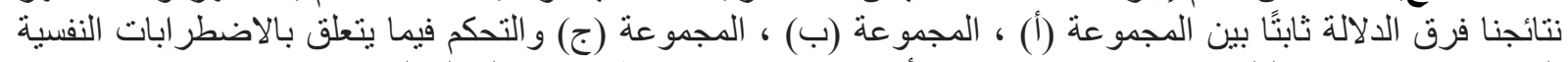

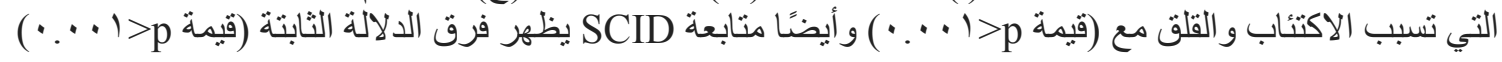
الخاتمة:تائجنا تثير إلى فحص الاضطر ابات النفسية لدى مرضى أمر اض القلب الإقفارية حيث انها أكثر انتشارًا في أمر اض القلب التاجية 